\title{
The coagulopathy associated with aortic aneurysms
}

\author{
E. Paul Gétaz* \\ M.B., Ch.B., M.R.C.P. \\ J. H. Louw \\ Ch.M., F.R.C.S. \\ Departments of Haematology and Surgery, Groote Schuur Hospital and the University of Cape Town
}

\section{Summary}

The authors in this article record their experience with eighty-four patients with abdominal aortic aneurysms. Twenty-seven patients $(32 \%)$ presented with ruptured aneurysms with an overall mortality of $56 \%$. Of the unruptured aneurysms, $67 \%$ were operable with a mortality of $5.3 \%$. The highest mortality amongst the patients with ruptured aneurysms was in the group who was shocked.

In the group with ruptured aneurysms, of those in whom platelet counts were performed, $50 \%$ were abnormally low, and $56 \%$ had evidence of abnormal coagulation. Seventy per cent of those with coagulation abnormalities died. In the unruptured group $28.2 \%$ had thrombocytopenia but no other abnormalities of coagulation.

All patients undergoing aneurysm resection should have a platelet count and a full clotting screen. Therapy should be directed to normalization of the coagulation system.

\section{Introduction}

Since the report of Dubost, Allary and Oeconomos (1952) aneurysmectomy with homograft replacement has become commonplace. There have been occasional reports of coagulation disorders associated with aortic aneurysms, but more recently ten Cate, Timmers and Becker (1975) reported four patients with ruptured or dissecting aortic aneurysms in whom a consumptive type of coagulopathy was demonstrated. In this paper eighty-four patients with the diagnosis of aortic aneurysm seen during an interval of eighteen months are reviewed, and the association between coagulopathy and aortic aneurysms is emphasized.

\section{Materials and methods}

Blood was collected into $10 \mathrm{ml}$ plastic centrifuge tubes containing one $\mathrm{ml}$ of $3.13 \%$ trisodium citrate. The platelet count (Bull, Schneiderman and Brecher, 1965) was performed with an electronic particle counter, and the coagulation parameters

\footnotetext{
* Present address: Department of Medical Oncology, Roswell Park Memorial Institute, 666 Elm Street, Buffalo, N.Y. 14263, U.S.A.
}

were screened by measurement of the prothrombin $\overrightarrow{\vec{\omega}}$ time (Quick, 1957) partial thromboplastic time ${ }^{\circ}$ (Biggs and MacFarlane, 1966) fibrinogen (Hannen, 8 1964) and fibrinogen degradation products (FDP) 3 . (Garvey and Black, 1972).

\section{Patients}

There were eighty-four patients of whom seventy- $\dot{-}$ three $(87 \%)$ were male and eleven female. Seventy- $\infty$ eight patients $(93 \%)$ were Caucasian and six were 을 coloured. There were no African patients. The average age was 67 years with a range of $36-95 z$ years (Table 1).

Table 1. Age distribution

\begin{tabular}{|c|c|c|c|c|}
\hline $\begin{array}{c}\text { Age group } \\
\text { (yrs.) }\end{array}$ & $\begin{array}{l}\text { No. of } \\
\text { patients }\end{array}$ & $\%$ & Ruptured & Unruptu \\
\hline $\begin{array}{l}30-39 \\
40-49 \\
50-59 \\
60-69 \\
70-79 \\
80-89 \\
90-99\end{array}$ & $\begin{array}{r}1 \\
3 \\
10 \\
45 \\
24 \\
0 \\
1\end{array}$ & $\begin{array}{r}1 \cdot 2 \\
3 \cdot 6 \\
12 \cdot 0 \\
53 \cdot 5 \\
28 \cdot 5 \\
0 \cdot 0 \\
1 \cdot 2\end{array}$ & $\begin{array}{r}0 \\
1 \\
2 \\
15 \\
8 \\
0 \\
1\end{array}$ & $\begin{array}{r}1 \\
2 \\
8 \\
30 \\
16 \\
0 \\
0\end{array}$ \\
\hline Total & 84 & 100 & 27 & 57 \\
\hline
\end{tabular}

Twenty-seven patients $(32 \%)$ presented with ruptured aneurysms. Three were inoperable, and of the twenty-four operable patients, twenty-two had $\overline{0}$ resections of the aneurysm, and two had a palliative 3 . procedure, one aneurysm being wired and the second wrapped.

Fifty-seven patients $(68 \%)$ presented wtih unruptured aneurysms. Of these, thirty-eight $(67 \%)$ were operable and nineteen were considered to be ir- 의 resectable, or inoperable for medical reasons. $D$ Of the fifty-seven unruptured aneurysms, thirty $(53 \%)$ were asymptomatic and discovery of the aneurysm was incidental. The majority of the re- $\sigma$ maining twenty-seven patients complained of $\tilde{O}$ abdominal pain, backache, or a pulsatile abdominal $\underset{\omega}{N}$ swelling. Associated medical illnesses are given in $\widetilde{Q}$ Table 2. Of the patients with ischaemic heart disease, 0 $50 \%$ had suffered one or more documented myocardial infarctions, and of those with peptic ulcera- $\stackrel{\infty}{+}$ tion, four were gastric and three duodenal. 
TABLE 2. Associated medical illnesses

\begin{tabular}{lc}
\hline \multicolumn{1}{c}{ Illness } & Patients \\
\hline Hypertension & 38 \\
Peripheral vascular disease & 24 \\
Ischaemic heart disease & 22 \\
Peptic ulceration & 7 \\
Chronic obstructive airways disease & 4 \\
Cerebrovascular insufficiency & 2 \\
Diabetes mellitus & 2 \\
\hline
\end{tabular}

\section{Results}

\section{Coagulation studies}

Of the twenty-seven patients whose aneurysms had ruptured, eighteen $(67 \%)$ had platelet counts performed and nine of these $(50 \%)$ were abnormally low. Eleven of the patients $(41 \%)$ had a full clotting screen and a further three $(11 \%)$ had at least a prothrombin time performed. Four patients $(15 \%)$ had only a platelet count. The results are given in Table 3 . Ten of the eighteen patients $(56 \%)$ had one or more abnormal coagulation parameters, including two patients meeting the criteria for diagnosis of consumptive coagulopathy (Merskey et al., 1967).

Ten of the 57 patients $(18 \%)$ with unruptured aneurysms had coagulation screens and a further seven patients $(12 \%)$ had at least a prothrombin time measured. Thirty-nine patients $(68 \%)$ had platelet counts performed, and eleven of these $(28.2 \%)$ had thrombocytopenia. There were no other coagulation abnormalities. Of the eleven patients with thrombocytopenia, three were documented as having dramatic postoperative increases in the platelet count from
$128 \times 10^{9} / 1$ to $220 \times 10^{9} / 1$; from $54 \times 10^{9} / 1$ to $225 \times$ $10^{\circ} / 1$; and from $83 \times 10^{9} / 1$ to $340 \times 10^{9} / 1$, while a fourth patient rose from the low normal range of $182 \times 10^{9} / 1$ to $440 \times 10^{9} / 1$. One patient with a low platelet count pre-operatively had a bone marrow examination which demonstrated a normal marrow with increased numbers of megakaryocytes compatible with a peripheral destructive defect.

\section{Renal function}

Renal function was assessed in sixty-one unruptured and thirteen ruptured aneurysms. It was found to be abnormal in twelve $(19.6 \%)$ of the unruptured and four $(30.7 \%)$ of the ruptured aneurysms.

\section{Mortality}

As shown in Table 4, of the twenty-seven ruptured aneurysms, fifteen $(56 \%)$ died. Fourteen patients were shocked on presentation and $76 \%$ of these patients died. Of thirteen non-shocked patients, $31 \%$

TABLE 4. Mortality

\begin{tabular}{lcccc}
\hline & $\begin{array}{c}\text { No. of } \\
\text { patients }\end{array}$ & Deaths & $\begin{array}{c}\% \\
\text { Mortality }\end{array}$ & $\begin{array}{c}\text { Overall } \\
\% \\
\text { mortality }\end{array}$ \\
\hline Total ruptured & 27 & 15 & & 56 \\
$\begin{array}{l}\text { Shocked } \\
\text { Not shocked }\end{array}$ & 14 & 11 & $79 \cdot 0$ & 41 \\
Coagulation & 13 & 4 & $31 \cdot 0$ & 15 \\
abnormalities & 10 & 7 & $70 \cdot 0$ & \\
Total unruptured & 57 & & & \\
Operable patients & 38 & 2 & $5 \cdot 3$ & \\
\hline
\end{tabular}

TABLE 3. Coagulation studies in patients with ruptured aneurysms

\begin{tabular}{|c|c|c|c|c|c|c|c|}
\hline Patient & Survival & $\begin{array}{l}\text { Platelet count } \\
\text { n.r. } \\
150-400 \times 10^{9} / 1\end{array}$ & $\begin{array}{c}\text { Prothrombin index } \\
\text { n.r. } \\
80-100 \%\end{array}$ & $\begin{array}{l}\text { Partial } \\
\text { thromboplastin } \\
\text { time } \\
\text { (sec) }\end{array}$ & $\begin{array}{l}\text { Control } \\
\text { (sec) }\end{array}$ & $\begin{array}{c}\text { Fibrinogen } \\
\text { n.r. } \\
200-400 \mathrm{mg} / 100 \mathrm{ml}\end{array}$ & $\begin{array}{c}\text { FDPs } \\
\text { n.r. } \\
10<40 \mu \mathrm{g} / \mathrm{ml}\end{array}$ \\
\hline 1 & Died & 53 & 66 & 52 & 35 & 580 & $>80<160$ \\
\hline 2 & Died & 235 & 42 & 350 & 47 & 36 & $>640$ \\
\hline 3 & Survived & 83 & 69 & $>180$ & 47 & 240 & $>40<80$ \\
\hline 4 & Died & 108 & 74 & 73 & 49 & 298 & $>40<80$ \\
\hline 5 & Died & 64 & & & & & \\
\hline 6 & Survived & 80 & & & & & \\
\hline 7 & Died & 107 & & & & & \\
\hline 8 & Survived & 190 & 92 & 43 & $47 \cdot 5$ & 280 & $<10$ \\
\hline 9 & Survived & 126 & 90 & 40 & 40 & 530 & $>40<80$ \\
\hline 10 & Survived & 177 & 98 & & & & \\
\hline 11 & Survived & 270 & 100 & 36 & $46 \cdot 5$ & 470 & $>10<40$ \\
\hline 12 & Survived & 168 & 70 & & & & \\
\hline 13 & Died & 540 & 88 & & & & \\
\hline 14 & Survived & 360 & 89 & 45 & 46 & 520 & $>10<40$ \\
\hline 15 & Died & 80 & 68 & 52 & 48 & 180 & $>80<160$ \\
\hline 16 & Survived & 239 & 84 & 43 & $52 \cdot 5$ & & $>10<40$ \\
\hline 17 & Died & 106 & 89 & 52 & $41 \cdot 5$ & 375 & $<10$ \\
\hline 18 & Died & 269 & & & & & \\
\hline
\end{tabular}

n.r. = normal range 
died. Of the inoperable ruptured aneurysms all patients died. Both patients undergoing palliative procedures survived for discharge from hospital. Seventy per cent of those ruptured aneurysms with coagulation abnormalities died.

Only two $(5 \cdot 3 \%)$ of the thirty-eight patients with unruptured aneurysms who underwent operation died, one of small bowel volvulus with aspiration pneumonia and the second of pneumonia, ischaemic necrosis of the sigmoid colon and progressive renal failure.

\section{Discussion \\ Mortality}

The mortality of $56 \%$ in patients with ruptured aneurysms and $5.3 \%$ in upruptured aneurysms represents a significant decrease when compared to the earlier series of Louw et al. (1972) who had an overall mortality of $70 \%$ in ruptured and $11.6 \%$ in unruptured aneurysms. Those patients who were shocked had the greatest mortality and the most important factor is probably hypotension resulting from free intra-abdominal rupture with the ensuing anuria and cardiac arrest. Operative intervention is indicated in ruptured aneurysms since without repair the mortality is $100 \%$.

There is divergence of opinion as to whether asymptomatic aortic aneurysms should be resected. Louw et al. found that of unoperated patients, $19 \%$ survived for 5 years and, of those undergoing laparotomy without aneurysmectomy, the 5-year survival was $9 \%$. The overall 5-year survival of their patients without resection was $14 \%$ but there were no 10-year survivors. Szilagyi et al. (1966) and Foster et al. (1969) reported overall 5-year survivals in untreated patients of $19 \%$ and $18 \%$ respectively, and 10-year survival of $6 \%$ and $0 \%$ respectively. Data collected from various series shown that $10-20 \%$ of small aneurysms $(<6 \mathrm{~cm})$ and over $40 \%$ of large aneurysms rupture within 5 years of diagnosis. However, during this 5-year period a considerable proportion died of other causes, with the result that the 5-year survival rates are only $30 \%$ in those with small aneurysms and less than $10 \%$ in those with large aneurysms.

The policy adopted was to resect all aneurysms in good-risk patients, and large symptomatic aneurysms in borderline and poor-risk patients.

\section{Coagulopathy}

Fine et al (1967) reported the first case of dissecting aneurysm with multiple coagulation defects, but in a review of 505 cases by Hirst, Johns and Kime (1958) no mention was made of any abnormality in the coagulation system. In three subsequent papers on aortic aneurysms (Bromley, 1967; Mannick, 1967; Ottinger, 1975) no mention was made of thrombocytopenia or of bleeding diathesis.

Kazmier et al. (1969), Cutcudache, Brailescu and Gorun (1970), Straub and Kessler (1970) reported cases of consumption coagulopathy and Bieger et al. (1971) reported three further cases. Ten Cate et al. (1975) recently reported four patients, three with dissecting aneurysms and one with a leaking atherosclerotic aneurysm, who had abnormal coagulation parameters. One of their patients, however, had a Salmonella typhimurium septicaemia which may have contributed to the clinical picture (Gétaz and Staples, 1977).

Among eighteen patients with ruptured aneurysms in whom a platelet count was performed, $50 \%$ had an abnormally low count and two patients had the frank picture of a disseminated intravascular coagulation. In those with unruptured aneurysms, $28.2 \%$ had thrombocytopenia without other coagulation abnormalities. Bone marrow examination of one patient showed increased numbers of megakaryocytes and in four patients marked increase in platelet count was noted following the resection of the aneurysm.

The aneurysm itself may thus be the origin of the coagulopathy and contact with underlying aortis tissue, particularly pathological adventitia wit $\$$ increased fibrinolytic activity (Astrup and Cocchers 1962) may be the trigger. Contact with collagen has been shown to activate the intrinsic clotting system ${ }^{+}$ (Niewiarowski, Bankowski and Rogowicka, 1965) and Baumgartner, Stemerman and Spaet (1971) showed a rapid and intense deposition of platelets on denuded aorta. Local turbulence in flow in the diseased vessel, perhaps with localized thrombosis may also be a contributing factor. Straub and Kessler (1970) demonstrated localization of ${ }^{131} I-$ fibrinogen in the aneurysm of their patient, and after aneurysmectomy, the aneurysm contained a large mass of fibrin which gave a positive autoradiogram.

The single most important measurement in the clotting profile of these patients is the platelet count. Fifty per cent of patients with ruptured aneurysms are operated upon with abnormally low counts. In view of the urgency of the surgery, the blood used for transfusion is usually 'bank blood' with no platelets, and the massive quantities often required for pre- and intra-operative resuscitation ensure that the platelet count is further depressed, as are other coagulation factors (Ingram, 1965).

For the patient whose aneurysm has not ruptured, a pre-operative platelet count and coagulation screen should be done and, if necessary, platelet concentrate or whole fresh blood made available. In the patient with a ruptured aneurysm a platelet count should be 
performed immediately and if there is thrombocytopenia, platelet concentrates given when the aneurysm has been isolated from the circulation. After resection, it would appear that the coagulopathy corrects itself, but if there is excessive bleeding, fresh blood, or fresh frozen plasma and platelet concentrate should be given.

The mortality of operable patients whose aneurysms have not ruptured is acceptably low, but that for patients presenting with a ruptured aneurysm could be improved. Detection and treatment of abnormalities of the coagulation system should contribute to a significant reduction in mortality by ensuring better intra-operative haemostasis, and less leakage on release of the aortic clamps. Both these factors decrease the duration of anaesthesia.

Garg, Lackner and Karpatkin (1972) have shown that in those patients with peripheral destruction of platelets, there is an increased percentage of large young platelets so that platelet sizing may be a rapid and easy method of demonstrating the increased platelet turnover of a peripheral consumptive defect.

\section{Acknowledgments}

We wish to thank Ms N. Horn, Ms M. Bracher and Ms J. Hughes for expert technical assistance, Professor P. Jacobs for encouragement, and the Medical Superintendent for permission to publish.

\section{References}

Astrup, T. \& Coccheri, S. (1962) Thromboplastic and fibrinolytic activity of the arteriosclerotic human aorta. Nature. London, 193, 182.

Baumgartner, H.R., Stemerman, M.B.\& Spaet, T.H. (1971) Adhesion of blood platelets to subendothelial surface: distinct from adhesion to collagen. Experientia, 27, 283.

Bieger, R., Vreeken, J., Stibbe, J. \& Loeliger, E.A. (1971) Arterial aneurysm as a cause of consumption coagulopathy. New England Journal of Medicine, 285, 152.

Biggs, R. \& MACFARLANE, R.G. (1966) The Treatment of Haemophilia and other Coagulation Disorders, p. 344. Blackwell Scientific Publications, Oxford.

Bromley, L.L. (1967) Thoracic aneurysms. Postgraduate Medical Journal, 43, 61.

Bull, B.S., Schneiderman, M.A. \& Brecher, G. (1965) Platelet counts with the Coulter counter. American Journal of Clinical Pathology, 44, 678.

Cutcudache, C., Brallescu, G. \& Gorun, V. (1970) Intravascular coagulation in cancer, dissecting aneurysm and allergic reaction to heparin (abstract). XIIIth International Congress on Haematology, p. 107. Munich, Germany, 1970.
Dubost, C., Allary, M. \& Oeconomos, N. (1952) Resection of an aneurysm of the abdominal aorta. Archives of Surgery, 64, 405.

Fine, N.L., Applebaum, J., Elguezabal, A. \& Castleman, L. (1967) Multiple coagulation defects in association with dissecting aneurysm. Archives of Internal Medicine, 119, 522.

Foster, J.H., Bolasny, B.L., Gobbel, W.G., JR \& Scott, H.W. (1969) Comparative study of elective resection and expectant treatment of abdominal aortic aneurysm. Surgery, Gynecology and Obstetrics, 129, 1.

GARG, S.K., LACKNER, H. \& KARPATKIN, S. (1972) Increased percentage of megathrombocytes in various clinical disorders. Annals of Internal Medicine, 77, 361.

GARVEY, M.B. \& BLACK, J.M. (1972) The detection of fibrinogen/fibrin degradation products by means of a new antibody-coated latex particle. Journal of Clinical Patho$\log y, 25,680$.

Gétaz, E.P. \& Staples, W.G. (1977) Typhoid fever presenting as immune thrombocytopenic purpura. South African Medical Journal, 51, 3.

HANnen, C. (1964) Bloedstollingsonderzoek, p. 59. Scheltema Hoekema N.V., Amsterdam.

HiRst, A.E., JR, JoHns, V.J., JR \& Kime, S.W. (19\$8) Dissecting aneurysm of the aorta: a review of 505 cases. Medicine. Baltimore, 37, 217.

INGRAM, G.I.C. (1965) Editorial Review. The bleeding complications of blood transfusion. Transfusion, $\mathbf{5}, 1$.

Kazmier, F.J., Didisheim, P., Fairbanks, V.F., LudWig, J., PAYNe, W.S. \& BowIE, E.J.W. (1969) Intravascular coagulation and arterial disease. Thrombosis et diathesis haemorrhagica (Suppl.), 36, 295.

Louw, J.H., Terblanche, J., Birkenstock, W. \& Shippel, R. (1972) Abdominal aortic aneurysms. South African Medical Journal, 46, 1218.

MANNICK, J.A. (1967) Diagnosis of ruptured aneurysm of the abdominal aorta. New England Journal of Medicine, 276, 1305.

Merskey, C., Johnson, A.J., Kleiner, G.J. \& Wohl, H. (1967) The defibrination syndrome: clinical features and laboratory diagnosis. British Journal of Haematology, 13, 528.

Niewiarowski, S., Bankowski, E. \& Rogowicka, I. (1965) Studies on the adsorption and activation of the Hageman factor (factor XII) by collagen and elastin. Thrombosis et diathesis haemorrhagica, 14, 387.

OTTINGER, L.W. (1975) Ruptured arteriosclerotic aneurysms of the abdominal aorta. Journal of the American Medical Association, 233, 147.

Quick, A.J. (1957) The Haemorrhagic Diseases. p. 365. Henry Kimpton, London.

StRAUB, P.W. \& KeSSLER, S. (1970) Umsatz und Lokalisation von $I^{131}$ Fibrinogen bei chronischer intravasaler Gerinnung. Schweizerische Medizinische Wochenschrift, 100, 2001.

Szilagyi, D.E., Smith, R.F., De Russo, F.J., Elliott, J.P. \& SHERRIN, F.W. (1966) Contribution of abdominal aortic aneurysmectomy to prolongation of life. Annals of Surgery, $164,678$.

ten Cate, J.W., Timmers, H. \& Becker, A.E. (1975) Coagulopathy in ruptured or dissecting aortic aneurysms. American Journal of Medicine, 59, 171. 